\title{
Adopting a Strategic Approach to Matching People to Jobs
}

\author{
Chalette Renee Griffin ${ }^{1}$ \\ ${ }^{1}$ School of Business and Leadership, Regent University, Virginia Beach, United States of America \\ Correspondence: Chalette Renee Griffin, School of Business and Leadership, Doctor of Strategic Leadership \\ Program, Regent University, Virginia Beach, USA. E-mail: crg2690@icloud.com
}

Received: January 11, 2018

Accepted: February 18, 2018

Online Published: March 18, 2018

doi:10.5539/ijbm.v13n4p1

URL: https://doi.org/10.5539/ijbm.v13n4p1

\begin{abstract}
This conceptual analysis explores recruiters' ability to utilize the practice of strategic foresight to scan internal and external environments as a strategic plan to matching people to jobs. In today's volatile market, it is no longer useful for recruiters to attract and hire talent with a desultory mindset when filling open positions without considering internal and external factors. Today's recruiters must become more deliberate in who they hire by having a tactical plan to attract and retain the most qualified people in an unpredictable global market. Through the process of developing a conceptual framework model, this paper aims to present three strategic foresight competencies required for recruiters to match people to jobs. Also, this conceptual analysis will argue the need for recruiters to possess a strategic mindset to attract and hire the most qualified people to an organization. Furthermore, discuss the implications of recruiters who lack strategic foresight competencies. The practice of strategic foresight is now a requirement for recruiters to become cognizant of internal and external factors such as competitive behavior, technological change, political and economic conditions and human capital, which can influence their approach to matching people to jobs. Overall, when recruiters match talent based on the company's strategic drivers rather than blindly fill open positions without a tactical plan, organizations can better achieve its performance potential.
\end{abstract}

Keywords: hiring process, organizational performance, productivity, recruitment, strategic foresight, strategic thinking

\section{Introduction}

Global competition has forced companies to improve productivity through the alignment of organization strategies (Becton \& Schraeder, 2009). As a result, it is imperative that human resource professionals contribute to the organization's bottom line through strategic business priorities (Longenecker \& Fink, 2013). Recruiters have the responsibility of finding talent to help position companies for optimal performance (Abang Ekhsan, 2009). To support overall business goals, recruiters need to possess a strategic approach to matching people to jobs (Hughes \& Rog, 2008). In a volatile market, it is no longer useful for recruiters to attract and hire talent with a desultory mindset when filling open positions without considering internal and external factors (Al-Bahiri, 2015; Jeffery \& McKee, 2011). Today's global environment requires recruiters to become deliberate in who they hire by having a tactical plan to attract and retain the most qualified people (Abang Ekhsan, 2009). Although tactical methods are unique to each organization, successful ones include strategic foresight competencies coupled with the knowledge, skills, and abilities of the recruiter, to assess and evaluate specific talent needs of the company (Taneja et al., 2013). Before considering a strategic approach to matching people to jobs, the theory of the traditional recruiting method must be explored and developed, to provide a foundation for the conceptual analysis.

\section{Theoretical Analysis of the Traditional Recruitment Method}

In a global survey, human resource professionals stated that "the ability to attract and retain talent as the top people management issue in their organization" (Saks \& Uggerslev, 2010; Hughes \& Rog, 2008). Recruitment serves as a technique to identify and attract potential employees with the knowledge, skills and abilities organizations need to maintain a competitive advantage (Johnson et al., 2014; DeGrassi, 2012). Recruiters are responsible for evaluating and assessing candidates whom they believe will add value to the organization (Hofhuis et al., 2016). An efficient and adequate recruitment process attracts the most qualified candidates while reducing lack of fit and lowering employee turnover (DeGrassi, 2012). 
However, the traditional recruitment method requires recruiters to sift through hundreds of thousands of on-line job board resumes from applicants (Bateson et al., 2014). This process has the potential to yield a significant number of unsuitable applicants, which in turn, produce a less qualified applicant pool. Recruiters are not only disappointed they were unable to find suitable applicants but also, frustrated they spent time and resources without a return on investment (Humphrey, 2014). Also, “"serial applicants' or job seekers who apply to more than one position concurrently on a job board," were noted as the reason for the increase of unqualified candidates (Bateson et al., 2014). The traditional method of matching people to jobs through the sourcing of hundreds of thousands of resumes from on-line job boards has contributed to the increased cost of recruiting talent (Bates, 2015).

\subsection{The 'Post and Pray' Recruitment Approach}

'Post and pray' is a practice where recruiters 'post' an open position to an on-line job board and 'pray' they will receive qualified candidates (Jeffery \& McKee, 2011). Recruiters just sit back and wait for candidates to apply for positions on the job board (Bates, 2015). This laid-back approach is a traditional method of recruiting which enables companies to hire the talent they need with little or no effort at all (Jeffery \& McKee, 2011). However, as recruiters from various industries and sectors began to utilize the 'post and pray' approach to finding talent, the number of on-line job board applicants have "multiplied due to the ease of application combined with a greater catchment area" (Bateson et al., 2014). The traditional method of recruiting has become convoluted, due to the inundation of applicant resumes from job boards (Jeffery \& McKee, 2011). In 2011, a survey of U.S. recruiters showed the average number of applicants per job in the U.S. was 118 while the screening of resumes from on-line job boards took an average of 9.5 hours per job post (Bateson et al., 2014). Recruiters are taking longer to review resumes due to the volume of job board applicants.

\subsection{The Problem with the 'Post and Pray' Recruitment Approach}

The main problem with the 'post and pray' approach is that it does not target specific candidates. Bates (2015) argued that the search for talent is targeted and personal (Saks \& Uggerslev, 2010). Choudhury (2012) also argued that recruiters possess better control of applicant volume when they can target candidates based on a set criteria. When recruiters target applicants by matching their skills to the organization needs and requirements, they can better match people to jobs. According to Jeffrey \& McKee (2011), "candidates have choices to determine where they want to work",... as a result, "recruiters must ...chase them down and seal the deal." Jeffrey \& McKee (2011) further explained that "recruitment should not feel like a roulette wheel in which recruiters 'spin' for the right person...who is looking for a job at that moment in time...with the right skill set." As mentioned earlier, recruiters need to be deliberate in who they hire to adopt a strategic approach to matching people to jobs. However, when recruiters use the practice of strategic foresight, they are less dependent upon solely utilizing the 'post and pray' recruiting approach to find and match talent to jobs.

\section{What is Strategic Foresight?}

In general, strategic foresight is "the practice of creating a functional view of the future, or future events and possibilities, in such a way as to take full advantage of opportunities, as well as to prepare for any possible adversity" (Wise Geek, 2017). "Strategic foresight focuses on the most probable future of some specified phenomenon if things simply continue as they are," and considers external factors which can alter the future" (Bell, 1997). The concept of strategic foresight and its "strategy principles date back to early Chinese philosophers and ancient scholars" (Chermack, 2011). Military leaders have been utilizing strategic foresight to create 'what if' scenarios to determine plausible outcomes (Hirsch et al., 2013). According to Cattell (2002) "strategic planning using scenarios emerged in the 1950's at the RAND Corporation where it was popularized by Herman Kahn in the context of military planning." Pierre Wack of Royal Dutch/Shell adopted the scenario planning concept to challenge decision makers' assumptions (Chermack, 2011; Cattell, 2002). As a result, the practice of strategic foresight enables leaders to anticipate many risks and opportunities that could confront them in the future. "The goal of strategic foresight is to make better, more-informed decisions in the present to anticipate what is coming... by comparing 'what can happen'... with 'what the organization would like to see happen'..." (Hines, 2006). When leaders understand the alternatives to their desired futures, they can become more innovative (Inayatullah, 2008). However, strategic foresight is not a practice of fortune telling where "a correct future" or "a prediction of what will happen" is reported (Hines, 2006). Strategic foresight provides organizations more than one futures to consider (Bell, 1997). In essence, strategic foresight empowers leaders to take a look at other possibilities which could impact the preferred or desired state (Hines, 2006). The practice of strategic foresight is not only imperative for leaders to possess, but also, recruiters who can utilize it to understand internal and external forces which impact their ability to match people to jobs. 


\section{Internal Forces Impacting Recruitment}

\subsection{Strategic Drivers}

Organizations work diligently to achieve a competitive advantage to increase market share and profit for longevity success (Greco et al., 2013). Sustainable companies "possess an innovative and competitive strategy that fosters a unique and valuable position in the industry" (Moon \& Ruona, 2015). Strategic drivers are internal forces organizations utilize to determine their success in their market. Strategic drivers are also known as "factors of competitive success,' 'key success factors' and 'key value propositions' (Hughes et al., 2014), which are competitive advantages companies utilize to differentiate themselves in their industry (Moon \& Ruona, 2015; Budayan et al., 2013). Sheehan \& Foss (2007), also explained that strategic drivers are "generic, structural factors under management control, which impact value by an activity...that represents the firm and the context of the business value system the firm operates in." For example, some companies may differentiate their business through customer service while others may do so with rewards and incentives. Strategic drivers not only vary for each business activity but also, across industries (Budayan et al., 2013). Strategic drivers play a vital role in positioning a company to gain an advantage over its competitors by customizing its own, "processes, technology, knowledge, human and organizational factors, rather than 'copy-pasting' other organizations' strategies" (Ghinea \& Moroianu, 2016).

From a recruiter's perspective, it is vital to know the organization's strategic drivers to integrate HR practices with corporate strategy (Al-Bahiri, 2015). Recruiters are in a unique position to find employees who possess the right abilities and skills to support the strategic objectives of the organization (Ghinea \& Moroianu, 2016). Strategic drivers serve as a roadmap for recruiters to find talent which complements and support critical success factors. Experts stated that "HR systems such as selection, training... should be tailored to match the company's growth objectives..." (Al-Bahiri, 2015). It is necessary that recruiters understand the overall business goals of the organization to attract talent based on the needs of the company (Humphrey, 2014). By possessing a strategic approach, recruiters can ensure they are matching talent to the right jobs based on the organization's strategic drivers. One internal strategic driver recruiters can utilize to gain a competitive edge in matching people to jobs is the candidate engagement experience.

\subsubsection{Candidate Engagement Experience}

Personalized and open communication to job seekers is another way recruiters can gain a competitive advantage (Recruitment Goes Viral, 2013; Jeffery \& McKee, 2011; Russell \& Havel, 2010). Many organizations refrain from cultivating a long-term relationship with candidates' due to complexity and cost (Allden \& Harris, 2013). Strategic recruiters cultivate relationships with candidates to leave a positive impression, so candidates will want to work for the organization (Russell \& Havel, 2010). However, strategic recruiters understand that candidates are also potential consumers or ambassadors to the company's products and services (Jeffery \& McKee, 2011). Kajanová et al., (2017), posited that recruiters "need to see candidates as potential customers, partners, and future employees regardless of their current experience level or fit within their company." According to Allden \& Harris (2013), "it is the sharing and exchange of information within the network that sustains longevity." As a result, it is in the best interest of recruiters to communicate with potential job seekers through online talent community forums to "deny competitors access to the best human resource assets" (Allden \& Harris, 2013). On-line talent community forums allow for potential candidates to engage with recruiters to learn more about the company, information about job openings and the hiring process. Candidates who have a positive experience with a recruiter who communicates with them through a transparent hiring process, are more likely to refer friends or other colleagues (Russell \& Havel, 2010; Saks \& Uggerslev, 2010).

The screening process is also an area a recruiter can gain an advantage in the war for talent. Some companies do not consider the candidate engagement experience as a strategic way to differentiate themselves from their competitors. According to a talent engagement report, " 47 percent of candidates wait to hear back from recruiters after more than two months after they applied for a position." The talent engagement report further stated, "only 20 percent of candidates are notified by email that they are no longer considered for the position", while "only 8 percent of these candidates receive a telephone call to learn they are no longer considered for the job" (Talent Board, 2016). The lack of feedback from recruiters is a complaint often heard by candidates (Recruitment Goes Viral, 2013). Recruiters who use candidate engagement to take advantage of opportunities their competitors do not see or overlook in cultivating relationships have a better chance of finding and matching people to jobs (Kajanová et al., 2017). 


\subsubsection{Organizational Structure}

Another internal strategic driver recruiters can utilize to gain a competitive edge in matching people to jobs is the organizational structure. Recruiters must also consider their organizational structure when they are matching people to jobs. The method in which organizations receive and process information within the hierarchy impacts the efficiency and effectiveness of corporate performance (Yildiz, 2012). It is essential recruiters match candidates to the organizational structure so that they can perform well within the hierarchy. For instance, a matrix organizational structure consists of a dual authority between functional and divisional hierarchies (Harris \& Raviv, 2002). Cheng and Chang (2012) argued that in a matrix configuration, employees may possess "insufficient absorptive capacity" ... in which employees are unable to react "to the change of a situation" due to the layout of the organizational structure. As a result, employees may become confused to which priorities to focus on in a dual coordination across functions and divisions in a matrix configuration (Burton et al., 2015). If a recruiter is seeking to fill an open position in a matrix organization, it is essential the recruiter seeks qualified candidates who know how to perform in a matrix, dual authority environment.

From a strategic perspective, recruiters need to ask questions about the candidates' skills and qualifications in working in a matrix hierarchy or assessing the candidates' ability to serve in one. Thus, organizational design experts also reported that in a matrix organization, "the 'two-boss' system can create power struggles and task confusion" (Lee et al., 2015). The use of strategic foresight enables recruiters to determine the type of skills candidates will need, based on internal and external factors to perform in a specific organizational structure. Strategic foresight allows organizations to scan environmental factors to anticipate risk and opportunities that could confront them in the future (Inayatullah, 2008). It is important for recruiters also to utilize strategic foresight, to understand how a candidate's inability to perform in a specific organizational design can interfere with performance on the job. Strategic recruiters set the criteria and selection standard when they ask themselves, "What kind of people do best in this job" (Choudhry, 2012)? This type of question and analysis set the tone for strategically matching people to jobs. Internal drivers such as candidate engagement and organizational structures, serve as two examples of how recruiters can gain a competitive edge in finding talent to matching people to jobs. These internal success factors have the potential to help companies differentiate themselves from their competitors to gain strategic leverage.

\section{External Forces Impacting Recruitment}

\subsection{Market Trends, Changes and Conditions}

External forces, on the other hand, are conditions, trends and changes the organization does not have control over; however, they still must prepare for them. "Competitive behavior, technological change, political and economic conditions and human capital..." are some of the many external factors which influence recruiter's approach to matching people to jobs (Al-Bahiri, 2015). External forces such as an aging population and decreasing pool of qualified candidates are challenges recruiters must deal with in finding talent (Holm, 2014). Also, the recent political and legal changes which impact the way employers in the United States hire foreign workers, adds to the pressure of matching people to jobs (Maurer, 2017). As a result of these competing forces, recruiters must become analytical and adaptive.

\subsection{Threats}

According to Ralston \& Wilson (2006), businesses will need to become "adaptive systems that work organically to find, capture, interpret and act on cues from an ever-changing environment." In other words, organizations that rapidly change their practices, processes, methods, and procedures to adapt to market turbulence or become proactive in the face of change, are in a better position to anticipate threats and turn them into opportunities (Ralston \& Wilson, 2006; Marsh et al., 2002). In fact, it is imperative recruiters possess the ability to anticipate threats by scanning their environments for data, trends or ideas which can impede how they find quality candidates (Hughes et al., 2014; Hines, 2006). Cornish (2004) defined the process of scanning as "identifying significant changes in the external environment...in the world beyond our immediate area of operations...". Cornish (2004) further explained that scanning is "the effort to identify and understand phenomena or aspects of the world that are most relevant to people... who need this information to make important decisions." By scanning the marketplace for turbulence, recruiters can collect early signs of change to make better, more informed decisions in finding talent (Hines, 2006; Ralston \& Wilson, 2006; Schultz, 2006; Marsh et al., 2002). Unfortunately, some recruiters operate in reactive mode by responding to market turbulence after it has impacted the organization (Hammoud \& Nash, 2014). For some companies, blindly filling open positions without considering external factors is the status quo and a standard practice (Palomino et al., 2012). However, this approach lacks strategic foresight, since being 
'reactive' is not a best practice to model nor serve as an advantage for organizations (Hammoud \& Nash, 2014; Hirsch et al., 2013).

\section{Recruiters' Mindset}

Strategic thinking requires an ongoing process of collecting and analyzing information to determine best outcomes (Graetz, 2002; Marsh et al., 2002). As a result, forward-thinking organizations hire recruiters who utilize the practice of strategic foresight to monitor changes and trends in their field of expertise to better secure organizational outcomes (Ismail \& Karkoulian, 2013). A recruiters' mindset reflects how they make decisions and their awareness of internal and external factors, perceptions, and biases which can influence their approach to matching people to jobs (Ismail \& Karkoulian, 2013; Fontaine, 2008). The conceptual framework model (Figure 1) proposes three strategic foresight competencies recruiters need to adopt a strategic approach to matching people to jobs: (1) to use analytical and creative skills, (2) to scan internal and external environments for trends and changes, and (3) to use strategic drivers and unpredictability.

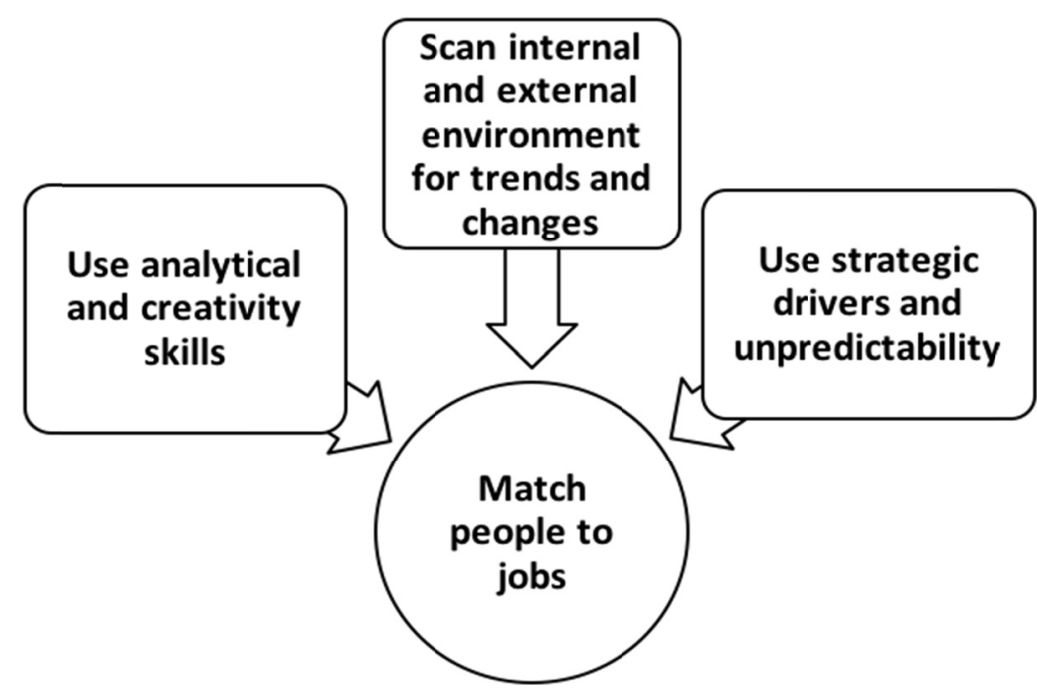

Figure 1. Conceptual Framework Model to Matching People to Jobs

\subsection{Analytical and Creativity Skills}

The first competency in the conceptual framework model (Figure 1) is the recruiters' creativity and analytical ability. Recruiters need to possess the analytical ability to challenge professional assumptions and beliefs based on past success (Moon \& Ruona, 2015). The notion that "we have always done it this way" is no longer an acceptable nor sustainable practice. To solve present and future problems, recruiters can no longer rely on past methods (Sullivan, 2000). For example, the traditional recruiting process matches people to jobs based on candidates' years of experience (Griffin, 2017). Recruiters match people to positions with the notion that candidates with the most experience outperform the candidates with less experience. However, empirical evidence supports that the number of years of experience does not predict performance (Griffin, 2017; Sullivan, 2000). Despite the empirical evidence, some recruiters continue to weigh experience as a sole indicator of future performance. Strategic thinking requires being receptive to new ideas and a different way/ of doing things. Being analytical and creative requires an innovative method of performing to produce desired results (Moon \& Ruona, 2015).

Also, organizations interpret the word 'experience' differently based on their talent needs and assumptions (Ismail \& Karkoulian, 2013; Fontaine, 2008; Sullivan, 2000). Being strategic requires hiring people who can move the business into the future. Recruiters who practice strategic foresight targets candidates who can provide not only the skills needed to meet today's job demands but also, provide skills and competencies required to meet future requirements outside of the current job description (Humphrey, 2014; Choudhury, 2012). A strategic process supported by analytical skills, creativity, and innovation, is now required to match people to jobs. 


\subsection{Scan Internal and External Environment for Trends and Changes}

The second competency in the conceptual framework model (Figure 1) requires recruiters to use their analytical skills to scan for changes and trends in the internal and external environments which have the potential to impact how they recruit and match people to jobs (Ismail \& Karkoulian, 2013; Fontaine, 2008). It is important for recruiters to look for changes and trends in various places to learn and anticipate what changes are coming and how they will impact their recruiting efforts. Recruiters who utilize strategic foresight are looking for signals of change and discontinuities from sources such as "politics, regulation, culture, consumer behavior, public opinion, business processes, science and technology" (Ralston \& Wilson, 2006). When recruiters scan their environment for changes, they can better prepare for their desired and preferred future (Hines, 2006). A strategic process supported by the recruiter's ability to scan environments for trends and changes is now required to match people to jobs.

\subsection{Strategic Drivers and Unpredictability}

The third competency in the conceptual framework model (Figure 1) is the recruiters' ability to use organizational strategic drivers and market turbulence as a competitive advantage. Since unpredictability and uncertainty remain unchanged, recruiters must continue to be creative in utilizing differentiation to stand out from their competitors (Nyuur, 2015; Holm, 2014). Differentiation in products, services or even a philosophy in the way of doing business, are drivers recruiters utilize to match people to jobs. One method in which recruiters can differentiate themselves from their competitors is by seeking passive candidates to match people to jobs (Jeffery \& McKee, 2011). Passive candidates are qualified people who are not actively seeking employment (Talent Board, 2016). A talent survey reported that "only $10 \%$ of relevant experienced talent is looking for a role at any given moment of time... which means that $90 \%$ of candidates relevant for a role is not looking and the best candidates are typically among them" (Jeffery \& McKee, 2011). Rather than use the 'post and pray' traditional approach to matching people to jobs, recruiters must consider shifting their focus to seeking passive candidates. As a result, recruiters will have more control to 'hand-pick' and target candidates whose qualifications and background align with strategic drivers of the organization (Al-Bahiri, 2015; Bates, 2015; Jeffery \& McKee, 2011). A strategic process supported by the recruiter's ability to use strategic drivers and unpredictability as a competitive advantage is now required to match people to jobs.

\section{The Process of Strategic Thinking}

The conceptual framework model (Figure 1) suggests that if recruiters lack analytical and creativity skills, they will face a challenge trying to satisfy the remaining competencies in the model. Strategic thinkers are often analytical and intuitive. Moon \& Ruona (2015), stated that the "process of strategic thinking requires a cognitive process, which depends on an individual's understanding of the context of the strategy." Experts also described the process of strategic thinking as "having a system perspective, being intent-focused...and acting in an intelligently opportunistic manner" (Nuntamanop et al., 2013). As a result, the process of strategic thinking "seeks new and different futures that may lead a company to redefine its core strategies..." (Nuntamanop et al., 2013). Experts further noted that strategic thinkers possess an understanding that the world is complicated and they need to make sense out of the chaos by breaking down complexities to determine the relationship of each part of the system or issue (Nyuur, 2015; Wayland, 2015). In other words, strategic thinkers look for commonalities to learn how to use chaos and unpredictability as a driver to success (Abraham, 2005). Recruiters must become strategic thinkers by possessing a methodical process in their approach to matching people to jobs.

\section{The Case for Strategic Foresight Competencies}

In today's environment, recruiters can benefit from adopting a strategic mindset since there are internal and external factors which can impact the hiring process (Nandakumar et al., 2010). As presented in the conceptual framework model (Figure 1), matching people to jobs requires recruiters to possess specific analytical competencies and skills to help organizations remain competitive. According to Hughes et al., (2014), strategic recruiters who possess foresight competencies "free themselves from silo thinking, seek beyond self-imposed constraints which focus attention on information within a limited domain and seek out perspective from others." Hughes et al., (2014), further stated that strategic recruiters "have an eye for anomalous data" and possess the disposition to look around for potentially useful information which can help or hinder their search to finding talent. It is vital that recruiters possess a new way of thinking concerning their approach to recruiting people to jobs. Today's recruiters "will need to attract and retain employees quite different from the people they replace, and they will need to adjust their targeting, their channels, and their over-all strategies accordingly" due to external factors impacting the recruitment process (Hughes \& Rog, 2008). 


\section{A Strategy to Matching People to Jobs}

A strategic recruitment approach is necessary to match people to jobs because the right people are needed to help position a company to reach organizational goals. Without the right people in jobs, a company's strategy to compete in the market fails. Also, a strategic approach to recruitment helps decrease the chances of hiring unfit people in jobs which cost the organizations thousands of dollars in lost productivity, employee turnover and resources (Hughes \& Rog, 2008). In fact, the Harvard Business Review reported that 80 percent of turnover is caused by bad hiring decisions (Choudhury, 2012). Job advertising fees, staff time, training fees and litigation expenses are some of the cost employers incur when replacing a bad hire (Fryre, 2017). The estimated cost of replacing a bad hire is approximately one-third of a new hire's salary (Choudhury, 2012). Recruiters play an active role in decreasing employee turnover since they are responsible for hiring talent. It is vital recruiters have a tactical plan to reduce employee turnover. When recruiters use their analytical and creativity skills to scan environments for trends and changes while using the company's strategic drivers and unpredictability to assess and find talent, the organization can invest in bringing people onboard that will achieve its performance potential (Khalifa, 2008).

\section{Implications for Lacking Strategic Foresight Competencies}

Recruiters who fail to recognize the need to possess strategic foresight competencies will lose the ability to assist their organizations in responding to change (Nuntamanop et al., 2013; Esmaeili, 2012; Kenny, 2006). It is imperative that recruiters become cognizant of external forces which impacts an organizations' internal activities and processes (Cornish, 2004). Recruiters who are unaware of environmental changes and forces in a global economy have the potential to increase their chances of being unprepared to respond to them, which in turn, hinders their ability to attract talent (Ralston \& Wilson, 2006; Marsh et al., 2002). For example, based on the United States presidential election outcome in 2016, President Donald Trump and his administration initiated changes to the H-1B visa process which impacted recruiting efforts for organizations (Maurer, 2017). Forward-thinking recruiters who anticipated how the political climate change in the United States would impact their hiring efforts were in an advantageous position to create alternative hiring strategies. Research supported the premise that recruiters who possess strategic foresight competencies are in a better position to anticipate changes to their hiring strategy (Esmaeili, 2012; Kenny, 2006). As a result, forward-thinking recruiters utilized their analytical skills to look for data, information and domestic and international changes and trends which supported or interfered in their hiring approach to matching people to jobs (Hughes et al., 2014).

Organizations rely on the expertise of recruiters to help gain a competitive advantage through hiring strategies (Abang Ekhsan, 2009). Without strategic foresight competencies, recruiters are left to operate reactively to environmental changes and events (Hammoud \& Nash, 2014; Humphrey, 2014; Choudhury, 2012). Furthermore, a recruiter's lack of strategic foresight has the potential to increase employee turnover and recruitment costs, due to hiring unqualified candidates (Frye, 2017; DeGrassi, 2012). The 'post and pray' recruiting approach lacks strategic foresight since it relies on chance, coincidence and luck to find and match people to jobs (Jeffrey \& McKee, 2011). Furthermore, the 'post and pray' recruiting approach hinders organizations in finding and hiring talent, which in turn, weakens their fundamental value proposition (Bates, 2015; Humphrey, 2014).

\section{Conclusion}

Recruiters can no longer assume that internal and external environments are undeviating and linear. They must possess strategic foresight competencies in looking for changes in trends and forces which can interfere with matching people to jobs. If recruiters do not own the required analytical abilities to scan the environments for such changes, recruiters will cost organizations money and resources. However, recruiters can learn strategic foresight competencies if they are willing to step outside of their comfort zone to grasp new ideas and a calculated way of recruiting talent. In essence, recruiters must shed their fear of the unknown by challenging the status quo of the traditional recruiting method. In a volatile market, the conventional practice of hiring to fill an open position without a hiring strategy is no longer a valid method for recruiters. The impulse to quickly fill a job opening without taking the time to review and evaluate internal and external factors threatens an organization's performance. The recruiters' tactical plan in utilizing foresight competencies along with strategic drivers to match people to jobs, has the potential to better position companies to finding and recruiting talent to meet organizational demands. A strategic approach to matching people to jobs is now required to not only remain competitive in a turbulent market but also methodically spend resources.

\section{References}

Abang Ekhsan, A. O. (2009). Recruitment selection and training development practices: Value-added contribution towards organizational effectiveness. Annals of University of Bucharest, Economic and 
Administrative $\quad$ Series, $\quad 3, \quad 73-100 . \quad$ Retrieved from http://annalseas.faa.ro/en/article/Recruitment-Selection-and-Training-Development-Practices-Value-AddedContribution-towards-Organizational-Effectiveness $\sim 165$.html

Abraham, S. (2005). Stretching strategic thinking. Strategic \& Leadership, 33(5), 5-12. https://doi.org/10.1108/10878570510616834

Al-Bahiri, A. (2015). Strategic human resource management: A literature review. Journal of Competitiveness Studies, 23(3), 84-85.

Allden, N., \& Harris, L. (2013). Building a positive candidate experience: Towards a networked model of e-recruitment. The Journal of Business Strategy, 34(5), 36-47. https://doi.org/10.1108/JBS-11-2012-0072

Bates, S. (2015). 'Post and pray' has had its day. Society for human resource management online. Retrieved from https://www.shrm.org/ResourcesAndTools/hr-topics/talent-acquisition/Pages/Recruitment-advertising.aspx

Bateson, J. E. G., Wirtz, J., Burke, E., \& Vaughan, C. (2014). Psychometric sifting to efficiently select the right service $\quad$ Managing Service Quality, 24(5), 418-433. https://doi.org/10.1108/MSQ-04-2014-0091

Becton, J. B., \& Schraeder, M. (2009). Strategic human resources management: Are we there yet? The Journal for Quality and Participation, 31(4), 11-18.

Bell, W. (1997). The Purpose of Future Studies. The Futurist, 42-45.

Budayan, C., Dikmen, I., \& Birgonul, M. T. (2013). Investigation of drivers and modes of differentiation in turkish construction industry. Engineering, Construction and Architectural Management, 20(4), 345-364. https://doi.org/10.1108/ECAM-09-2011-0083

Burton, R. M., Obel, B., \& Hakonsson. (2015). Organizational Design: A Step by Step Approach (3rd ed.). Cambridge, United Kingdom: Cambridge University Press.

Cattell, K. S. (2002). Foresight, space and e-commerce. Facilities, 20(3), 145-162. https://doi.org/10.1108/02632770210423902

Chen, S., \& Chang, B. (2012). The effects of absorptive capacity and decision speed on organizational innovation: A study of organizational structure as an antecedent variable. Contemporary Management Research, 8(1), 27-50. https://doi.org/10.7903/cmr.7996

Chermack, T. J. (2011). Scenario planning in organizations: how to create, use and assess scenarios. San Francisco, California: Berrett-Koehler Publishers, Inc.,

Choudhury, J. (2012). Recruitment and retention strategies in changing scenario. Review of HRM, 1, 21-33.

Cornish, E. (2004). Futuring: The exploration of the future. Bethesda, Maryland: World Future Society.

DeGrassi, S. W. (2012). Go, stop, yield: The effect of ethical signals on recruitment outcomes. Journal of Leadership, Accountability and Ethics, 9(4), 30-43.

Esmaeili, A. (2012). Strategic human-resource management in a dynamic environment. Scientific and Technical Information Processing, 39(2), 85-89. https://doi.org/10.3103/S0147688212020037

Fontaine, R. (2008). Teaching strategic thinking. The Journal of Global Business Issues, 2(1), 87-94.

Fyre, L. (2017). The cost of a bad hire can be astronomical. Society of human resource management on-line. Retrieved from https://www.shrm.org/resourcesandtools/hr-topics/employee-relations/pages/cost-of-bad-hires.aspx

Graetz, F. (2002). Strategic thinking versus strategic planning: towards understanding the complementaries. Management Decision, 40(5), 456-462. https://doi.org/10.1108/00251740210430434

Greco, M., Cricelli, L., \& Grimaldi, M. (2013). A strategic management framework of tangible and intangible assets. European Management Journal, 31(1), 55. https://doi.org/10.1016/j.emj.2012.10.005

Ghinea, V. M., \& Moroianu, M. (2016). HR strategy - necessity or fad for business sustainability? Management \& Marketing. Challenges for the Knowledge Society, 11(2), 458-469. https://doi.org/10.1515/mmcks-2016-0009

Griffin, C. R. (2017). Is past performance an accurate indicator of future performance in evaluating candidates' success in a future job? A conceptual analysis. International Journal of Business and Social Science, 8(1), 79-84. 
Hammoud, M. S., \& Nash, D. P. (2014). What corporations do with foresight. European Journal of Futures Research, 2(1), 1-20. https://doi.org/10.1007/s40309-014-0042-9

Harris, M., \& Raviv, A. (2002). Organization Design. Management Science, 48(7), 852-865. https://doi.org/10.1287/mnsc.48.7.852.282

Hines, A. (2006). Strategic foresight: The state of the art. Futurist, 40(5), 18-21.

Hirsch, S., Burggraf, P., \& Daheim, C. (2013). Scenario planning with integrated quantification - managing uncertainty in corporate strategy building. Foresight: The Journal of Futures Studies, Strategic Thinking and Policy, 15(5), 363-374. https://doi.org/10.1108/FS-09-2012-0064

Hofhuis, J., Van Der Zee, K. I., \& Otten, Sabine (2016). Dealing with differences: The impact of perceived diversity outcomes on selection and assessment of minority candidates. The International Journal of Human Resource Management, 27(12), 1319-1339. https://doi.org/10.1080/09585192.2015.1072100

Holm, A. B. (2014). Institutional context and e-recruitment practices of Danish organizations. Employee Relations, 36(4), 432-455. https://doi.org/10.1108/ER-07-2013-0088

Hughes, J. C., \& Rog, E. (2008). Talent management: a strategy for improving employee recruitment, retention and engagement with hospitality organizations. International Journal of Contemporary Hospitality Management, 20(7), 743-757. https://doi.org/10.1108/09596110810899086

Hughes, R. L., Beatty, K. C., \& Dinwoodie, D. L. (2014). Becoming a strategic leader: Your role in your organization's enduring success (2nd ed.). San Francisco, CA: Jossey-Bass.

Humphrey, S. (2014). Recruiters and applicants: An exchange of words. Journal of Financial Services Marketing, 19(2), 94-103. https://doi.org/10.1057/fsm.2014.8

Inayatullah, S. (2008). Six pillars: Futures thinking for transforming. Foresight, 10(1), 4-21. https://doi.org/10.1108/14636680810855991

Ismail, H., \& Karkoulian, S. (2013). Interviewers' characteristics and post-hire attitudes and performance. Contemporary Management Research, 9(4), 441-462. https://doi.org/10.7903/cmr.10453

Jeffery, M., \& McKee, A. (2011). A guide to recruitment 3.0. Journal of Corporate Recruiting Leadership, 6(5), 12-34.

Johnson, G., Wilding, P., \& Robson, A. (2014). Can outsourcing recruitment deliver satisfaction? A hiring manager perspective. Personnel Review, 43(2), 303-326. https://doi.org/10.1108/PR-12-2012-0212

Kajanová, H., Sedlácek, M., \& Soósová, V. (2017). Attitudes of young people to job searching through social media: Case of Slovakia. Economics \& Sociology, $10(1), \quad 152-168$. https://doi.org/10.14254/2071-789X.2017/10-1/11

Kenny, J. (2006). Strategy and the learning organization: A maturity model for the formation of strategy. The Learning Organization, 13(4), 353-368. https://doi.org/10.1108/09696470610667733

Khalifa, A. S. ( 2008). The "strategy frame" and the four E's of strategy drivers. Management Decision, 46(6), 894-917. https://doi.org/10.1108/00251740810882662

Lee, J., Kozlenkova, I. V., \& Palmatier, R. W. (2015). Structural marketing: Using organizational structure to achieve marketing objectives. Academy of Marketing Science. Journal, 43(1), 73-99. https://doi.org/10.1007/s11747-014-0402-9

Longenecker, C. O., \& Fink, L. S. (2013). Creating human-resource management value in the twenty-first century: Seven steps to strategic HR. Human Resource Management International Digest, 21(2), 29-32. https://doi.org/10.1108/09670731311306814

Marsh, N., McAllum, M., \& Purcell, D. (2002). Why strategic foresight? Extract from Strategic foresight - The power of standing in the future. Australia: Crown Content.

Maurer, R. (2017). USCIS Suspends H-1B Visa Premium Processing. Society of human resource management on-line. $\quad$ Retrieved from https://www.shrm.org/resourcesandtools/hr-topics/talent-acquisition/pages/uscis-suspends-h1b-visa-premiu m-processing.aspx

Moon, H., \& Ruona, W. (2015). Towards a deeper understanding of strategic learning. Leadership \& Organization Development Journal, 36(6), 657-674. https://doi.org/10.1108/LODJ-10-2013-0139 
Nandakumar, M. K., Ghobadian, A., \& O'Regan, N. (2010). Business-level strategy and performance. Management Decision, 48(6), 907-939. https://doi.org/10.1108/00251741011053460

Nuntamanop, P., Kauranen, I., \& Igel, B. (2013). A new model of strategic thinking competency. Journal of Strategy and Management, 6(3), 242-264. https://doi.org/10.1108/JSMA-10-2012-0052

Nyuur, R. B. (2015). Unlocking the potential barriers on SMEs' uptake of scenario planning. Journal of Strategy and Management, 8(2), 139-154. https://doi.org/10.1108/JSMA-01-2014-0007

Palomino, M. A., Bardsley, S., Bown, K., De Lurio, J., Ellwood, P., Holland-Smith, D., . . Owen, R. (2012). Web-based horizon scanning: Concepts and practice. Foresight: The Journal of Futures Studies, Strategic Thinking and Policy, 14(5), 355-373. http://doi.org/10.1108/14636681211269851

Ralston, B., \& Wilson, I. (2006). Scan ${ }^{\mathrm{TM}}$ : Radar for signals of change. In The scenario-planning handbook: A practitioner's guide to developing and using scenarios to direct strategy in today's uncertain times (pp. 245-257). Mason, OH: South-Western.

Recruitment goes virtual. (2013). Human Resource Management International Digest, 21(3), 19-21.

Russell, J., \& Havel, S. (2010). Candidate marketing takes the guessing game out of choosing employers. Nursing Economics, 28(3). 195-197.

Saks, A. M., \& Uggerslev, K. L. (2010). Sequential and combined effects of recruitment information on applicant reactions. Journal of Business and Psychology, 25(3), 351-365. https://doi.org/10.1007/s10869-009-9142-0

Schultz, W. L. (2006). The cultural contradictions of managing change: Using horizon scanning in an evidence-based policy context. Foresight: The Journal of Futures Studies, Strategic Thinking and Policy, 8(4), 3-12. https://doi.org/10.1108/14636680610681996

Sheehan, N. T., \& Foss, N. J. (2007). Enhancing the prescriptiveness of the resource-based view through porterian activity analysis. Management Decision, 45(3), 450. https://doi.org/10.1108/00251740710745070

Sullivan, J. (2000). Experience -- it "ain't what it used to be": It's time to kill the sacred cow of job experience in recruiting. Public Personnel Management, 29(4), 511-516. https://doi.org/10.1177/009102600002900409

Talent Board.org (2016). Talent Board North American Candidate Experience Research Report. Retrieved from http://www.thetalentboard.org/article/talent-boards-2016-north-american-candidate-experience-research-rep ort-now-available/

Taneja, S., Pryor, M. G., Humphreys, J. H., \& Singleton, L. P. (2013). Strategic management in an era of paradigmatic chaos: Lessons for managers. International Journal of Management, 30(1), 112-126.

Wayland, R., (2015). Strategic foresight in a changing world. Foresight, 17(5), 444-459. https://doi.org/10.1108/FS-03-2015-0016

Wise Geek (2017). What is Strategic Foresight? Retrieved from http://www.wisegeek.com/what-is-strategic-foresight.htm

Yildiz, M. (2012). The future of organizational design: A forecasting study. METU Studies in Development, 39(2), $259-282$

\section{Copyrights}

Copyright for this article is retained by the author(s), with first publication rights granted to the journal.

This is an open-access article distributed under the terms and conditions of the Creative Commons Attribution license (http://creativecommons.org/licenses/by/4.0/). 